\title{
Pengaruh Model Pembelajaran SAVI Berbantuan Multimedia Terhadap Kompetensi Pengetahuan IPA
}

\author{
Komang Adi Muliarta \\ Program Studi Pendidikan Guru Sekolah Dasar, Universitas Pendidikan Ganesha \\ komang.adi.muliarta@undiksha.ac.id \\ I Gusti Agung Oka Negara \\ Program Studi Pendidikan Guru Sekolah Dasar, Universitas Pendidikan Ganesha \\ igustiagungoka.negara@undiksha.ac.id \\ I Wayan Wiarta \\ Program Studi Pendidikan Guru Sekolah Dasar, Universitas Pendidikan Ganesha \\ iwayan.wiarta@undiksha.ac.id
}

\begin{tabular}{l} 
A R T I C L E I N F O \\
\hline Article history: \\
1 Juli 2020 Received in \\
revised form \\
30 Agustus 2020 \\
Accepted 28 September 2020 \\
Available online \\
30 September 2020
\end{tabular}

Kata Kunci:

Animasi dua dimensi,

tematik, ADDIE

two-dimensional animation,

thematic, ADDIE
Keywords:

\begin{abstract}
AB S T R A K
Pembelajaran yang cenderung menggunakan metode ceramah mengakibatkan siswa cepat merasa bosan dan rendahnya penguasaan kompetensi pengetahuan IPA. Oleh karena itu, penelitian ini dilaksanakan untuk mengetahui Pengaruh Model Pembelajaran SAVI Berbantuan Multimedia Terhadap Kompetensi Pengetahuan IPA Kelas V. Penelitian ini merupakan penelitian Quasi Eksperimen, dengan rancangan nonequivalent control group design. Populasi keseluruhan dalam penelitian ini seluruh kelas V sebanyak 269 siswa. Sampel yang digunakan yaitu 38 siswa kelas kontrol dan 39 siswa untuk kelas eksperimen. Sampel diperoleh dengan teknik cluster random
\end{abstract} sampling. Data kompetensi Pengetahuan IPA siswa dikumpulkan dengan Instrumen tes objektif. Selanjutnya data tersebut dianalisis menggunakan uji-t. Berdasarkan hasil analisis uji-t diperoleh $\mathrm{t}_{\text {hitung }}=3,380>\mathrm{t}_{\text {tabel }} 2,000$. Sehingga dapat disimpulkan terdapat pengaruh yang signifikan model pembelajaran SAVI terhadap kompetensi pengetahuan IPA kelas V. Hasil penelitian ini diharapkan dapat menjadi salah satu referensi dalam mengembangkan penelitian selanjutnnya. 


\section{PENDAHULUAN}

Pendidikan merupakan aspek yang sangat penting dalam kehidupan manusia, baik untuk manusia itu sendiri, orang lain, maupun suatu Bangsa. Menurut Gusnawan (2017) "Pendidikan yang baik adalah pendidikan yang memiliki landasan tujuan yang kokoh dan jelas". Peranan guru amatlah penting dalam menentukan kualitas pendidikan suatu bangsa (Yuniarti, 2019). Pendidikan yang mampu mendukung pembangunan di masa mendatang adalah pendidikan yang mampu mengembangkan potensi peserta didik, sehingga peserta didik mampu menghadapi dan memecahkan problema kehidupan yang dihadapinya (Pradika, 2017). Dalam upaya meningkatkan suatu sistem pendidikan perlu adanya suatu kurikulum. Kurikulum merupakan suatu pedoman dalam penyelenggaran kegiatan pembelajaran yang memiliki fungsi dan kedudukan di masing-masing jenjang pendidikan (Safitri, 2020). Kurikulum memiliki sifat yang dinamis, dalam artian kurikulum akan selalu beradaptasi mengikuti perkembangan yang ada (Febbriana, 2019).

Kurikulum yang diberlakukan saat ini adalah kurikulum 2013. Kurikulum 2013 merupakan salah satu upaya pemerintah untuk memperbaiki mutu pendidikan agar dapat mencetak manusia yang berkualitas dan mampu proaktif menjawab tantangan zaman yang selalu berubah (Dwipayana, 2017). Kurikulum 2013 bertujuan untuk mengembangkan potensi peserta didik baik kemampuan sikap religius, sikap sosial, intelektual, kemampuan berkomunikasi, sikap peduli, dan partisipasi aktif dalam membangun kehidupan bangsa dan bermasyarakat yang lebih baik (Rani, 2019). Dalam kurikulum 2013, pengembangan materi-materi yang dulu dirancang 1 mata pelajaran dikembangkan menjadi materi-materi terintegrasi dan terpadu dalam suatu tema yang disebut tematik terpadu. Pembelajaran tematik merupakan pendekatan pembelajaran dengan memadukan berbagai kompetensi dari berbagai materi ke dalam berbagai tema (Winata, 2017). Salah satu muatan materi yang terdapat pada tematik terpadu yaitu muatan materi IPA. IPA merupakan usaha dari manusia memahami alam melalui pengamatan untuk mendapat suatu kesimpulan" (Susanto, 2016). Dalam muatan materi IPA di sekolah dasar yang perlu diajarkan adalah produk dan proses IPA karena keduanya tidak dapat dipisahkan. Ilmu Pengetahua Alam (IPA) memegang peranan sangat penting dalam kehidupan manusia, hal ini disebabkan karena dalam kehidupan ini sangat tergantung dari alam, zat terkandung di alam, dan segala jenis gejala yang terjadi di alam. Pada proses pembelajaran perlu diciptakan kondisi pembelajaran IPA di SD yang dapat mendorong siswa aktif dan ingin tahu. Menurut Agustino (2017) pelajaran IPA dapat melatih anak untuk berpikir kritis dan objektif.

Berdasarkan observasi dan wawancara pada Rabu, 30 Oktober 2019 dengan guru wali kelas $\mathrm{V}$ permasalahan yang terjadi yaitu pembelajaran cenderung menggunakan metode ceramah dan menugaskan siswa membaca sendiri buku pelajaran lalu mengerjakan soal-soal yang ada di buku siswa yang mengakibatkan siswa cepat merasa bosan dan rendahnya penguasaan kompetensi pengetahuan IPA hal ini dapat dilihat dari hasil ulangan muatan pelajaran IPA kelas V SDN Gugus IV Pattimura Kecamatan Denpasar Selatan Tahun Ajaran 2019/2020 belum memenuhi Kriteria Ketuntasan Minimum atau KKM yaitu 70. Dari 270 siswa kelas V di SDN Gugus IV Pattimura Denpasar selatan 125 siswa atau 46,3\% siswa belum memenuhi Kriteria Ketuntasan Minimum (KKM). Di sisi lain memperlihatkan bahwa dalam proses pembelajaran jarang diterapkan model pembelajaran yang tepat dan inovatif. Kecenderungan penggunaan model pembelajaran konvensional di dalam kelas masih sering terjadi, artinya model pembelajaran yang digunakan selalu sama pada setiap kali pembelajaran berlangsung. Kemampuan dan ketepatan guru dalam 
memilih pendekatan, model maupun metode pembelajaran sangat diperlukan dalam proses pembelajaran. Dalam mempersiapkan pembelajaran, para pendidik harus memahami karakteristik materi pembelajaran, karakteristik murid atau peserta didik, serta memahami metodelogi pembelajaran sehingga proses pembelajaran akan lebih variatif, inovatif, dan konstruktif dalam memahami wawasan pengetahuan dan menjalankannya sehingga akan meningkatkan aktivitas dan kreativitas peserta didik (Ambarawati, 2020). Pada jenjang pendidikan dasar, seharusnya pembelajaran IPA di sekolah dasar dilakukan secara optimal dengan mengembangkan seluruh sumber daya dan kemampuan yang dimiliki siswa. Agar kompetensi pengetahuan IPA dapat tercapai secara optimal, hendaknya diciptakan suasana belajar yang tidak membosankan serta hendaknya menggunakan model pembelajaran yang tepat sehingga tercipta suasana kelas yang aktif dan kondusif.

Salah satu model pembelajaran yang dapat membuat proses pembelajaran menjadi menarik dan efektif untuk meningkatkan kompetensi pengetahuan IPA siswa adalah model pembelajaran Somatic Auditory Visualization Intellectualy. "Model pembelajaran Somatic Auditory Visualization Intellectualy adalah suatu model pembelajaran, dengan memanfaatkan seoptimal mungkin seluruh panca indra yang dimiliki oleh siswa serta kemampuan intelektual siswa dalam menangkap informasi'(Isrok'atun, 2018). "Pembelajaran SAVI menekankan bahwa belajar haruslah memanfaatkan semua alat indra yang dimiliki siswa" (Shoimin, 2014).

SAVI dirancang untuk meningkatkan keterlibatan siswa dalam pembelajaran, sehingga nantinya dapat meningkatkan hasil belajar siswa (Juliawan, 2013). Model pembelajaran SAVI tidak hanya terfokus pada pikiran dan intelektual siswa saja, tetapi juga terdapat aktivitas tubuh dan panca indra secara keseluruhan serta dapat memberikan kesempatan belajar siswa dalam pembelajaran dengan gaya belajar masing-masing siswa sehingga mencapai hasil belajar yang optimal. Artinya dalam pembelajaran siswa tidak hanya duduk diam, tetapi dengan aktivitas yang menggerakkan seluruh inderanya. Dari beberapa pendapat tersebut dapat dirangkum bahwa, model pembelajaran SAVI adalah model pembelajaran yang memanfaatkan seluruh panca indra dan melibatkan gerakan fisik dengan aktivitas intelektual siswa dalam proses pembelajaran sehingga mencapai hasil belajar yang optimal. Model pembelajaran Somatic Auditory Visualization Intellectualy mengajak peserta didik untuk belajar dengan bergerak, mendengar, mengamati, dan memecahkan masalah sehingga hasil belajar siswa lebih optimal. "Adapun keunggulam dari model pembelajaran SAVI yaitu sebagai berikut, (1) membangkitkan kecerdasan terpadu siswa, (2) siswa membangun sendiri pegetahuannya, (3) memupuk kerjasama karena siswa yang lebih pandai diharapkan dapat membantu yang kurang pandai, (4) memunculkan suasana belajar yang lebih baik, menarik, dan efektif, (5) mampu membangkitkan kreativitas dan (6) meningkatkan kemampuan psikomotor siswa serta siswa akan lebih termotivasi untuk belajar lebih baik" (Cemara, 2019).

Disamping model pembelajaran inovatif seperti model pembelajran SAVI, pembelajaran juga akan lebih efektif apabila adanya motivasi dan minat belajar peserta didik. Salah satu yang dapat mempengaruhi minat belajar peserta didik adalah penggunaan media atau alat peraga. Memilih media yang tepat untuk meningkatkan minat belajar peserta didik merupakan hal yang sangat penting. Perkembangan teknologi yang sangat pesat dapat kita manfaatkan sebagai media untuk membantu proses pembelajaran. Salah satu teknologi tersebut adalah multimedia, multimedia merupakan media yang dapat menarik perhatian peserta didik sehingga dapat meningkatkan minat belajar dari peserta 
didik .Multimedia adalah media yang digunakan dari berbagai bentuk konten informasi dan pemrosesan informasi (misalkan audio, grafik, dan video) untuk menginformasikan, menghibur, atau mendidik pengguna (Mujiarto, 2019). Menurut Batchelder (dalam Simarmata \& Mujiarto,2019) "multimedia adalah kombinasi teks, grafik, animasi, video, dan suara yang disampaikan kepada audiens yang dijadikan sebagai pembelajar, pendengar atau pemirsa melalui sarana elektronik". Multimedia merupakan perpaduan berbagai bentuk elemen informasi yang diguanakan sebagai sarana menyampaikan tujuan tertentu (Pratiwi, 2020).

Pembelajaran dengan multimedia melibatkan hampir semua indera. Elemen-elemen dari multimedia adalah teks, gambar dan grafik, audio, video, dan animasi (Simarmata \& Mujiarto, 2019: 3). Berdasarkan pendapat tersebut dapat dirangkum multimedia adalah kombinasi media yang digunakan dari berbagai bentuk konten informasi dan pemrosesan informasi yang berupa teks, gambar dan grafik, audio, video, dan animasi yang disampaikan kepada audiens dan dijadikan sebagai pembelajar, menghibur dan mendidik. "Multimedia dapat memberi daya tarik dan motivasi tersendiri bagi peserta didik. Hal ini disebabkan tayangan-tayangan yang terdapat di dalamnya dilengkapi dengan unsur-unsur gambar, suara, dan gerak yang dapat ditampilkan secara simultan" (Dewi, 2020).

Adapun selanjutnya penelitian yang mendukung dilakukan (Astuti, 2013)(2013,Vol 1) Menyatakan bahwa model pembelajaran SAVI bermuatan mind mapping berpengaruh terhadap hasil belajar IPA siswa kelas IV Sekolah Dasar Gugus III Mengwi Tahun Ajaran 2012/2013, yang dibuktikan dengan bahwa thitung $=3,597>$ ttabel $=2,000$ dan diperoleh rata-rata hasil belajar kelompok eksperimen yaitu 75,80 sedangkan kelompok kontrol yaitu 64,54. Persamaan dengan penelitian ini adalah Model Pembelajaran yang diterapkan dan mata pelajaran yang digunakan. Adapun perbedaannya adalah kelas yang digunakan, tempat dan tahun penelitian serta pada penelitian ini menggunakan berbantuan Multimedia. Serta Penelitian yang dilakukan (Karwati, 2018) Menyatakan bahwa model pembelajaran probing prompting berbantuan multimedia berpengaruh terhadap hasil belajar IPA siswa kelas V SD Gugus I Kecamatan Kuta Utara tahun ajaran 2017/2018, yang dibuktikan dengan bahwa thitung $=4,517>$ ttabel $=2,000$ dan diperoleh rata-rata hasil belajar kelompok eksperimen yaitu 80,89 sedangkan kelompok kontrol yaitu 72,85. Persamaan dengan penelitian ini adalah Berbantuan yang diterapkan dan kelas yang digunakan. Adapun perbedaannya adalah model pembelajaran yang digunakan serta tempat dan tahun penelitian. Dalam penelitian (Nena, 2013) juga berpendapat pendekatan pembelajaran Somatic Auditory Visual and Intellectual (SAVI) berpengaruh signifikan terhadap hasil belajar IPA pada siswa kelas IV di Sekolah Dasar Nomor 1 Kuta, Kabupaten Badung Tahun Pelajaran 2013/2014. Perbedaan pada penelitian ini yaitu tempat dan waktu penelitian serta kelas. (Kasmayuda, 2013)juga berpendapat bahwa penerapan model pembelajaran SAVIberorientasi keterampilan proses sains berpengaruh terhadap hasil belajar IPA siswa kelas V SD Gugus V Kecamatan Tejakula, Kabupaten Buleleng. Perbedaan dengan penelitian ini yaitu media pembelajaran, tempat dan waktu serta kelas.

Berdasarkan penjelasan di atas dapat dirangkum bahwa model pembelajaran somatic, auditory, visualization, intellectualy berbantuan multimedia adalah model pembelajaran yang memanfaatkan seluruh panca indra dan melibatkan gerakan fisik dengan berbantuan media yang berupa teks, gambar dan grafik, audio, video, dan animasi yang dapat mengoptimalkan proses pembelajaran Berdasarkan pemaparan yang telah diuraikan, maka dilaksanakan penelitian Pengaruh Model Pembelajaran Somatic Auditory 
Visualization Intellectualy Berbantuan Multimedia Terhadap Kompetensi Pengetahuan IPA Kelas V SDN Gugus IV Pattimura Denpasar Selatan Tahun Ajaran 2019/2020. tujuan dari penelitian ini adalah untuk mengetahui pengaruh yang signifikan model pembelajaran Somatic Auditory Visualization Intellectualy berbantuan multimedia terhadap kompetensi pengetahuan IPA kelas V SDN Gugus IV Pattimura Kecamatan Denpasar Selatan Tahun Ajaran 2019/2020.

\section{METODE PENELITIAN}

Penelitian ini dilaksanakan di Gugus IV Pattimura Denpasar Selatan .Jenis penelitian yang dilakukan dalam penelitian ini adalah penelitian kuantitatif. Dalam penelitian ini unit eksperimennya berupa kelas, sehingga penelitian yang digunakan adalah penelitian eksperimen semu (Quasi-Eksperimental Design). Rancangan eksperimen semu yang digunakan adalah "Non-equivalent Control Group Design". "Dalam rancangan ini ada dua kelompok subjek, satu mendapat perlakuan dan satu kelompok sebagai kelompok kontrol"(Setyosari, 2016). Rancangan yang digunakan melibatkan dua kelompok kelas, yaitu kelompok kelas ekspeimen dan kelompok kelas kontrol. Satu kelompok kelas sebagai kelompok eksperimen yang mendapatkan perlakuan dengan menggunakan model pembelajaran Somatic Auditory Visualization Intellectually berbantuan multimedia dan satu kelompok kelas tidak menggunakan model tersebut sebagai kelompok kontrol.

Pelaksanaan penelitian dilaksanakan di SDN 7 Sesetan sebagai Kelas eksperimen yang beralamat di JL. Tegal Wangi No.54 dan SDN 18 Sesetan sebagai kelas kontrol yang beralamat di JL. Batas Dukuh Sari GG Beo. Dalam penentuan subjek penelitian, langkah awal yang dilakukan dalam penelitian ini adalah menentukan populasi yang akan diteliti. "Populasi adalah keseluruhan dari kumpulan semua anggota yang ingin diamati" (Suciutari, 2013). "Populasi adalah keseluruhan dari objek yang menjadi kajian dalam penelitian" (Setyosari, 2016). Selanjutnya "populasi adalah keseluruhan dari subjek maupun objek yang menjadi target dari hasil akhir dalam penelitian yang memiliki kualitas dan karakteristik tersebut"(Prasetya, 2018) . Jadi dapat disimpulkan populasi adalah keseluruhan dari objek yang menjadi kajian dalam suatu penelitian .Populasi dari penelitian ini adalah seluruh kelas V SDN Gugus IV Pattimura Kecamatan Denpasar Selatan yang terdiri dari 7 kelas dalam 5 sekolah dasar jumlah populasi ini adalah 269 orang. Setelah mengetahui populasi langkah selanjutnya adalah menentukan sampel penelitian. "Sampel adalah bagian dari jumlah dan karakteristik yang dimiliki oleh populasi tersebut " (Sugiyono, 2018). "sampel adalah bagian dari populasi yang mewakili anggota populasi" (Wahyuni, 2018). Selanjutya "sampel adalah sebagian dari populasi yang diambil, yang mewakili seluruh populasi dan diambil menggunakan teknik tertentu"(Agung, 2014). Jadi dapat disimpulkan sampel merupakan bagian dari populasi yang mewakili anggota populasi serta diambil menggunakan teknik tertentu.

Dari populasi kelas V SDN Gugus IV Pattimura Kecamatan Denpasar Selatan tahun ajaran 2019/2020, untuk menentukan kelas eksperimen dan kelas kontrol peneliti akan menggunakan teknik sampling. "Teknik sampling adalah merupakan teknik pengambilan sampel" (Sugiyono, 2018). Teknik sampling yang digunakan adalah teknik cluster random sampling. "cluster random sampling memilih sampel bukan didasarkan individual, akan tetapi didasarkan kelompok, daerah, atau kelompok subjek yang secara alami berkumpul bersama. Dalam teknik ini setiap kelas memiliki peluang atau kesempatan untuk menjadi 
sampel penelitian. Pemilihan sampel pada penelitian ini tidak dilakukan pengacakan individu melainkan hanya pengacakan kelas.

Untuk menentukan sampel, cara yang digunakan adalah dengan cara pengundian. Cara undian dilakukan dengan menulis semua kelas V di seluruh SD populasi pada masingmasing kertas yang jumlahnya 7 kelas, kemudian kertas digulung. Masukkan gulungan kertas ke dalam kotak dan lakukan pengundian untuk mendapatkan dua kelas. Dua kelas tersebut kemudian diberikan pre test. hasil pre test digunakan untuk penyetaraan dengan teknik uji-t. Setelah setara, kedua kelas diundi untuk mendapatkan kelas kontrol dan kelas eksperimen Kesetaraan sampel diuji dengan rumus uji-t yakni dengan polled varian. Sebelum dilakukan uji kesetaraan kelas dari seluruh anggota populasi dengan uji-t, terlebih dahulu dilakukan uji prasyarat analisis yakni dengan melakukan uji normalitas dan uji homogenitas.

Data yang dibutuhkan pada penelitian ini yaitu kompetensi pengetahuan IPA siswa kelas V SDN Gugus IV Pattimura Denpasar Selatan. Untuk mendapatkan data tersebut digunakan metode tes dalam bentuk pilihan ganda biasa. Untuk memperoleh data penelitian ini menggunakan instrumen bentuk tes. Setelah tes sudah memenuhi syarat syarat uji validitas, uji daya beda, uji tingkat kesukaran dan uji reliabilitas pada penelitian ini menggunakan 32 butir soal untuk mengukur kompetensi pengetahuan IPA. Setiap butir soal di berikan 4 alternatif jawaban (a, b, c, dan d), bila setiap butir soal dijawab dengan benar akan diberikan skor satu dan apabila salah atau tidak menjawab diberikan skor nol. Skor setiap soal kemudian dijumlahkan, jumlah tersebut merupakan skor variabel kompetensi pengetahuan IPA. Langkah selanjutnya bila data sudah terkumpul, data tersebut selanjutnya dianalisis. Penggunaan analisis pada penelitian ini adalah dengan analisis statistik inferensial. Data gain skor yang dinormalisasi dari hasil pre test maupun post test dianalisis dengan statistik inferensial. Sebelum uji-t dilakukan, terlebih dahulu diuji prasyarat analisis yaitu uji normalitas sebaran data dan uji homogenitas varians. Teknik analisis pada penelitian ini menggunakan rumus polled varians yang digunakan pada uji-t yang digunakan pada penelitian ini.

Tabel 1. Kisi-kisi

\begin{tabular}{|c|c|c|}
\hline $\begin{array}{l}\text { Kompetensi Dasar } \\
\text { (KD) }\end{array}$ & Indikator & $\begin{array}{c}\text { Tipe } \\
\text { Kognitif }\end{array}$ \\
\hline \multirow{6}{*}{$\begin{array}{l}\text { Menganalisis Pengaruh } \\
\text { kalor terhadap } \\
\text { perubahan suhu dan } \\
\text { wujud benda dalam } \\
\text { kehidupan sehari-sehari }\end{array}$} & $\begin{array}{l}\text { Menjelaskan tentang sifat-sifat benda padat, } \\
\text { cair dan gas. }\end{array}$ & $\mathrm{C} 1$ \\
\hline & $\begin{array}{l}\text { Menjelaskan perubahan wujud benda mencair, } \\
\text { membeku, menguap, menyublim, mengembun, } \\
\text { dan mengkristal }\end{array}$ & $\mathrm{C} 1$ \\
\hline & $\begin{array}{l}\text { Menentukan peristiwa perubahan wujud benda } \\
\text { mencair, membeku, menguap, menyublim, } \\
\text { mengembun, dan mengkristal }\end{array}$ & $\mathrm{C} 3$ \\
\hline & $\begin{array}{l}\text { Mengidentifikasi wujud benda dan peristiwa } \\
\text { perubahan wujud benda }\end{array}$ & $\mathrm{C} 1$ \\
\hline & $\begin{array}{l}\text { Membedakan perubahan wujud benda mencair, } \\
\text { membeku, menguap, menyublim, mengembun, } \\
\text { dan mengkristal }\end{array}$ & $\mathrm{C} 2$ \\
\hline & $\begin{array}{l}\text { Menganalisis peristiwa perubahan wujud benda } \\
\text { padat, cair, dan gas. }\end{array}$ & $\mathrm{C} 4$ \\
\hline
\end{tabular}




\begin{tabular}{ll}
\hline $\begin{array}{l}\text { Menjelaskan perubahan wujud dan suhu benda } \\
\text { yang dipengaruhi oleh kalor atau panas. } \\
\text { Menganalisis perubahan suhu benda }\end{array}$ & $\mathrm{C} 1$ \\
\hline Yang dipengaruhi oleh kalor atau panas. & $\mathrm{C} 4$ \\
\hline
\end{tabular}

\section{HASIL DAN PEMBAHASAN}

\section{HASIL}

Data gain score kompetensi pengetahuan IPA kelompok eksperimen yang diberikan perlakuan dengan diberi kegiatan pelajaran menggunakan model pembelajaran somatic auditory visualization intellectualy berbantuan multimedia diperoleh rata-rata (means) sebesar 0,363, standar deviasi sebesar 0,201, varians sebesar 0,0406, gain skor maksimum sebesar 1,00, dan gain skor minimum sebesar 0,10. Setelah dikonversikan ke PAN Skala 5 (lima) Kelompok Eksperimen diperoleh pengkategorian pengetahuan IPA kelompok eksperimen yaitu berada pada kategori cukup. Sedangkan, data gain score kompetensi pengetahuan IPA kelompok Kontrol dengan pemberian perlakuan kegiatan belajar menggunakan pembelajaran konvensional didapatkan rata-rata (means) sebesar 0,223, standar deviasi sebesar 0,159, varians sebesar 0,0253, gain skor maksimum sebesar 0,57, dan gain skor minimum sebesar 0,07. setelah dikonversikan ke PAN Skala 5 (lima) Kelompok Kontrol diperoleh pengkategorian kompetensi pengetahuan IPA kelompok kontrol yaitu terdapat pada kategori cukup.

Tabel 2. Rekapitulasi Hasil Analisis Post-Test Kompetensi Pengetahuan IPA

\begin{tabular}{lcc}
\hline \multirow{2}{*}{ Statistik } & \multicolumn{2}{c}{ Kompetensi Pengetahuan IPA } \\
\cline { 2 - 3 } & Kelompok Eksperimen & Kelompok Kontrol \\
\hline Rata-rata $\overline{\mathrm{X}}$ & 0,363 & 0223 \\
Standar Deviasi (S) & 0,201 & 0,159 \\
Varians (S ${ }^{2}$ ) & 0,0406 & 0,0253 \\
Skor Tertinggi & 1,00 & 0,57 \\
Skor Terendah & 0,10 & 0,07 \\
\hline
\end{tabular}

Salah satu uji prasyarat analisis yaitu uji normalitas sebaran data. Uji normalitas dimaksudkan untuk mengetahui apakah sebaran data skor kompetensi pengetahuan matematika siswa masing-masing kelompok berdistribusi normal atau tidak sehingga dapat menentukan teknik analisis datanya. "penggunaan Statistik parametris mensyaratkan bahwa data setiap variabel yang akan dianalisis harus berdistribusi normal" (Sugiyono, 2017:171-172). Uji Normalitas sebaran data dalam penelitian ini menggunakan rumus Kolmogorov-Smirnov. Data berdistribusi normal apabila pada taraf signifikansi 5\%, |FTFS $\mid$ terbesar < tabel Kolmogorov smirnov. Berdasarkan hasil hitung uji normalitas kelompok eksperimen diperoleh |FT-FS| yaitu 0,197, dengan taraf signifikansi 5\% dan n = 39 diperoleh nilai tabel Kolmogorov smirnov yaitu 0,213. Hal tersebut menunjukan bahwa $0,197<0,213$ maka data kelompok eksperimen berdistribusi normal. Pada kelompok kontrol diperoleh |FT-FS| terbesar yaitu 0,168, dengan taraf signifikansi 5\% dan $\mathrm{n}=38$ diperoleh nilai tabel Kolmogorov smirnov yaitu 0,215. Hal tersebut menunjukan bahwa $0,168<0,215$ yang berarti data kompetensi pengetahuan IPA kelompok kontrol berdistribusi normal. 
Tabel 3. Hasil Uji Normalitas Kelompok Eksperimen dan Kelompok Kontrol

\begin{tabular}{cccccc}
\hline No & $\begin{array}{c}\text { Kelompok } \\
\text { Sampel }\end{array}$ & $\begin{array}{c}\text { Jumlah } \\
\text { Sampel }\end{array}$ & $\begin{array}{c}\text { Nilai } \\
\text { Maksimum } \\
\left|\mathbf{F}_{\mathbf{T}}-\mathbf{F}_{\mathbf{S}}\right|\end{array}$ & $\begin{array}{c}\text { Nilai Tabel } \\
\text { Kolmogorov- } \\
\text { smirnov }\end{array}$ & Kesimpulan \\
\hline 1 & $\begin{array}{c}\text { Kelompok } \\
\text { Eksperimen } \\
\text { Kelompok } \\
\text { Kontrol }\end{array}$ & 39 & 0,197 & 0,213 & $\begin{array}{c}\text { Berdistribusi } \\
\text { Normal } \\
\text { Berdistribusi } \\
\text { Normal }\end{array}$ \\
\hline
\end{tabular}

Uji prasyarat analisis selanjutnya adalah uji homogenitas varians. Uji homogenitas varians dilakukan terhadap data perolehan dari kedua kelompok. Tujuan dari dilakukannya uji homogenitas varians adalah untuk mengetahui varians homogen atau tidak. Pada uji homogenitas varians dipergunakan rumus yaitu dengan menggunakan uji $\mathrm{F}$ (fisher). Berdasarkan hasil perhitungan diperoleh $\mathrm{F}_{\text {hitung }}=1,60$, dengan taraf signifikansi 5\% dan $\mathrm{dk}$ pembilang n1-1(39-1=38) serta dk penyebut $\mathrm{n} 2-1(38-1=37)$ diperoleh $\mathrm{F}_{\text {tabel }}=1,72$. Hal ini menunjukan bahwa 1,60 < 1,72 sehingga data kedua kelompok adalah homogen.

Tabel 4. Hasil Uji Homogenitas Varians

\begin{tabular}{|c|c|c|c|c|c|c|}
\hline No & Sampel & Varians & Dk & $F_{\text {hitung }}$ & $F_{\text {tabel }}$ & Kesimpulan \\
\hline 1 & $\begin{array}{l}\text { Kelas } \\
\text { Eksperimen }\end{array}$ & 0,0406 & 38 & \multirow[b]{2}{*}{1,60} & \multirow[b]{2}{*}{1,72} & \multirow[b]{2}{*}{ Homogen } \\
\hline 2 & $\begin{array}{l}\text { Kelas } \\
\text { Kontrol }\end{array}$ & 0,0253 & 37 & & & \\
\hline
\end{tabular}

Setelah dilaksanakannya uji normalitas sebaran data maupun uji homogenitas varians diperoleh data yang berasal dari kedua kelompok dinyatakan berdistribusi normal dan mempunyai varians yang homogen. Maka dari itu, diperolehlah data yang sudah memenuhi uji prasyarat analisis, selanjutnya dapat dilaksanakan uji hipotesis yang menggunakan analisis uji-t yang digunakan adalah rumus polled varians. Kriteria pengujian dari uji-t yaitu jika $t_{\text {hitung }} \leq t_{t a b e l}$, dinyatakan $\mathrm{H}_{\mathrm{o}}$ diterima. Sedangkan jika $\mathrm{t}_{\text {hitung }}>\mathrm{t}_{\text {tabel }}$, dinyatakan $\mathrm{H}_{\mathrm{o}}$ ditolak, dengan $\mathrm{dk}=\mathrm{n} 1+\mathrm{n} 2-2$ pada taraf signifikansi $5 \%(\alpha=0,05)$. Berdasarkan analisis $\mathrm{t}_{\text {hitung }}=3,380>\mathrm{t}_{\text {tabel }}=2,000$, jadi $\mathrm{H}_{0}$ ditolak. Dapat dikatakan terdapat perbedaan yang signifikan kompetensi pengetahuan IPA kelompok yang dibelajarkan menggunakan model pembelajaran Somatic Auditory Visualization Intellectually berbantuan multimedia dengan kelompok yang dibelajarkan menggunakan pembelajaran konvensional pada kelas V SDN Gugus IV Pattimura Kecamatan Denpasar Selatan Tahun Ajaran 2019/2020.

Tabel 5. Uji Hipotesis

\begin{tabular}{ccccccccc}
\hline No & Sampel & $\mathbf{N}$ & $\mathbf{D k}$ & $\underline{\boldsymbol{X}}$ & $\mathbf{S}^{\mathbf{2}}$ & $\mathbf{t}_{\text {hitung }}$ & $\mathbf{t}_{\text {tabel }}$ & Simpulan \\
\hline 1 & Kelas & \multirow{2}{*}{39} & & 0,363 & 0,0406 & & & \\
2 & Eksperimen & & 75 & & & & \\
2 & Kelas Kontrol & 38 & & 0,223 & 0,0253 & & & $\mathrm{H}_{\mathrm{o}}$ ditolak \\
\hline
\end{tabular}

Rata - rata pada kelompok eksperimen dan kelompok kontrol sama-sama memiliki kategori cukup pada tabel klasifikasi PAN karena kurikulum yang diterapkan sama yaitu kurikulum 2013 dan sumber belajar yang digunakan pada kelompok kontrol dan kelompok eksperimen juga sama yaitu tematik.Dalam pembelajaran di kelas eksperimen peserta didik dibimbing untuk lebih aktif bergerak, mendengar, mengamati, serta memecahkan masalah 
sehingga hasil belajar siswa lebih optimal serta penggunaan media animasi yang disukai peserta didik dapat meningkatkan minat belajar peserta didik Sedangkan di kelas kontrol proses pembelajaran yang diterapkan adalah proses pembelajaran yang sehari-hari dipergunakan seperti guru menjelaskan, membagi siswa menjadi beberapa kelompok, dan memberikan tugas sehingga rata-rata pada kelas eksperimen lebih dari dibandingkan ratarata pada kelas control.

\section{PEMBAHASAN}

Model pembelajaran Somatic Auditory Visualization Intellectually berbantuan multimedia adalah Model pembelajaran dengan memanfaatkan seluruh panca indera yang dimiliki siswa yang dipadukan dengan multimedia sebagai media pembelajaran. Model pembelajaran SAVI tidak hanya terfokus pada pikiran dan intelektual siswa saja, tetapi juga terdapat aktivitas tubuh dan panca indra secara keseluruhan serta dapat memberikan kesempatan belajar siswa dalam pembelajaran dengan gaya belajar masing-masing siswa sehingga mencapai hasil belajar yang optimal. Dengan diterapkannya model ini siswa lebih bersemangat serta sangat antusias dalam menerima pembelajaran. Dari berbagai kegiatan yang dilaksanakan, terlihat bahwa siswa sangat termotivasi dalam mengikuti pembelajaran. Berbeda pada kelompok kontrol, proses kegiatan pembelajaran yang masih konvensional cenderung kurang maksimal mendorong pemahaman siswa terhadap materi pembelajaran. Kegiatan pembelajaran dengan menerapkan model pembelajaran Somatic Auditory Visualization Intellectually berbantuan multimedia memberikan hasil belajar khususnya dalam kompetensi pengetahuan IPA yang lebih tinggi, dikarenakan model ini memiliki keunggulan yaitu memanfaatkan seluruh panca indera yang dimiliki siswa. Hasil penelitian ini didukung oleh Adapun selanjutnya penelitian yang dilakukan (Astuti, 2013) Menyatakan bahwa model pembelajaran SAVI bermuatan mind mapping berpengaruh terhadap hasil belajar IPA siswa kelas IV Sekolah Dasar Gugus III Mengwi Tahun Ajaran 2012/2013 dan peneitian yang dilakukan (Karwati, 2018) Menyatakan bahwa model pembelajaran probing prompting berbantuan multimedia berpengaruh terhadap hasil belajar IPA siswa kelas V SD Gugus I Kecamatan Kuta Utara tahun ajaran 2017/2018. Dalam (Nena, 2013) juga berpendapat pendekatan pembelajaran Somatic Auditory Visual and Intellectual (SAVI) berpengaruh signifikan terhadap hasil belajar IPA pada siswa kelas IV di Sekolah Dasar Nomor 1 Kuta, Kabupaten Badung Tahun Pelajaran 2013/2014. (Kasmayuda, 2013) juga berpendapat bahwa penerapan model pembelajaran SAVIberorientasi keterampilan proses sains berpengaruh terhadap hasil belajar IPA siswa kelas V SD Gugus V Kecamatan Tejakula, Kabupaten Buleleng. Penerapan model pembelajaran Somatic Auditory Visualization Intellectually (SAVI) ini dipadukan dengan media pembelajaran multimedia interaktif yang dapat memperjelas materi yang disampaikan. Melalui multimedia interaktif, materi yang awalnya bersifat abstrak dapat diterjemahkan menjadi lebih konkrit sehingga mudah dipahami oleh siswa. Hat tersebut dikarenakan dalam multimedia interaktif materi dikemas sedemikian rupa dalam bentuk teks, suara, gambar, video dan animasi yang dapat menjadikan materi lebih jelas dan menarik, serta interaktif.

Berdasarkan paparan tersebut, dapat diimpulkan bahwa model pembelajaran Somatic Auditory Visualization Intellectualy berbantuan multimedia berpengaruh terhadap kompetensi pengetahuan IPA Kelas V SDN GugusIV Pattimura Denpasar Selatan tahun ajaran 2019/2020. 


\section{SIMPULAN}

Berdasarkan analisis dan pembahasan diperoleh bahwa thitung $=3,380>\mathrm{t}$ tabel $=$ 2,000 sehingga $\mathrm{H} 1$ diterima, maka dapat diketahui bahwa terdapat perbedaan yang signifikan kompetensi pengetahuan IPA kelompok yang dibelajarkan menggunakan model pembelajaran Somatic Auditory Visualization Intellectualy berbantuan multimedia dan kelompok yang dibelajarkan dengan 1 pembelajaran konvensional. Dari hal tersebut dapat direpresentasikan bahwa model pembelajaran Somatic Auditory Visualization Intellectualy berbantuan multimedia berpengaruh terhadap kompetensi pengetahuan IPA kelas V SDN Gugus IV Pattimura Kecamatan Denpasar Selatan Tahun Ajaran 2019/2020.

\section{DAFTAR PUSTAKA}

Agung, A. A. . (2014). Metodologi Penelitian Pendidikan. Malang: Adistya Media Publishing.

Agustino, I. K. (2017). Pengaruh Model Pembelajaran Inkuiri Berbasis Penilaian Kinerja Terhadap Kompetensi Pengetahuan IPA Siswa Kelas IV Gugus IX Abiansemal Kecamatan Abiansemal Tahun Pelajaran 2016/2017. MIMBAR PGSD,5(3).

Ambarawati, N. L. M. (2020). Efektivitas Model Pembelajaran (CIRC) Berbantuan Scramble Terhadap Kompetensi Pengetahuan IPA. MIMBAR PGSD, $8(.1)$

Anggreni, N. L. P. D. K. (2017). Pengaruh Model Pembelajaran Kooperatif Tipe Jigsaw Berbantuan Media Audio Visual terhadap Penguasaan Kompetensi Pengetahuan IPS Siswa Kelas IV SD Gugus 1 Dalung Tahun Ajaran 2016/2017. MIMBAR PGSD, 8 (1)

Astuti, N. P. A. W. (2013). Pengaruh Model Pembelajaran SAVI Bermuatan Mind Mapping Terhadap Hasil Belajar Ipa Siswa Kelas IV Sekolah Dasar Gugus III. MIMBAR PGSD, 1(1)

Cemara, G. A. G. (2019). Pengaruh Model Pembelajaran SAVI Bermuatan Peta Pikiran Terhadap Kreativitas dan Penguasaan Kompetensi Pengetahuan IPA Siswa. Jurnal Ilmiah Sekolah Dasar, 3(3)

Dewi, A. . Y. (2020). Pengaruh Model Pembelajaran Auditory Intellectually Repetition Berbantuan Multimedia Terhadap Kompetensi Pengetahuan IPA. MIMBAR ILMU, 25(1)

Dwipayana, I. M. (2017). Pengaruh Model Pembelajaran Kooperatif Tipe Jigsaw Terhadap Penguasaan Kompetensi Pengetahuan Ipa Siswa Kelas V Sd Gugus Kapten Kompyang Sujana Denpasar Barat Tahun Ajaran 2016/2017. MIMBAR PGSD, 5(3).

Febbriana, I. M. R. A. (2019). Pengaruh Model Pembelajaran Word Square Berbasis Outdoor Study Terhadap Kompetensi Pengetahuan IPA Siswa. MIMBAR PGSD, 7(2)

Gusnawan, I. M. V. (2017). Pengaruh Model Pembelajaran Resolusi Konflik Berbantuan Media Video Clip Terhadap Hasil Belajar PKN. MIMBAR PGSD, 5(3)

Isrok'atun. (2018). Model-Model Pembelajaran Matematika.

Juliawan, K. E. (2013). Pengaruh Pendekatan Savi Berbantuan Media Visual Terhadap Hasil Belajar IPA Siswa Kelas IV di SD No. 1 Sepang Kelod. MIMBAR PGSD, Volume 1 (1)

Kariani, N. K. (2014). Model Problem Based Learning Menggunakan Metode Probing - 
Prompting Berpengaruh Terhadap Hasil Belajar IPA Siswa. MIMBAR PGSD, 2(1).

Karwati, N. P. R. (2018). Pengaruh Model Pembelajaran Probing Prompting Berbantuan Multimedia Terhadap Hasil Belajar IPA Siswa Kelas V SD. MIMBAR ILMU, 23(2).

Kasmayuda, I. G. N. (2013). Pengaruh Model Pembelajaran SAVI Berorientasi Keterampilan Proses Sains Terhadap Hasil Belajar IPA Siswa Kelas V SD Gugus V Kecamatan Tejakula. MIMBAR PGSD, 1(1)

Mujiarto, S. dan. (2019). Multimedia Pembelajaran.

Nena, N. P. N. (2013). Pendekatan Pembelajaran Somatic Auditory Visual And Intellectual (SAVI) Berpengaruh Terhadap Hasil Belajar IPA Siswa Kelas IV SD No.1 Kuta. MIMBAR PGSD, 1(1).

Nilayanti, P. M. (2017). Pengaruh Model Pembelajaran Kooperatif Tipe Number Head Together Berbantuan Media Konkret Terhadap Kompetensi Pengetahuan IPA Siswa Kelas IV SD Gugus Kompyang Sujana Denpasar Utara. MIMBAR PGSD, 5(3).

Pradika, I. P. H. (2017). Pengaruh Model Pembelajaran Course Review Horey Berbantuan Permainan Teka-Teki Silang (TTS) Terhadap Kompetensi Pengetahuan IPS Siswa Kelas V SD Gugus Budi Utomo Dentim Tahun Pelajaran 2016/2017. MIMBAR $P G S D, 5(3)$

Prasetya, I. M. A. (2018). Pengaruh Model Pembelajaran Self Regulated Learning (SRL) Berbantuan LKS Terhadap Prestasi Belajar Matematika. MIMBAR PGSD, 6(3)

Pratiwi, N. P. D. (2020). Pengaruh Model Think Talk Write Berbantuan Multimedia terhadap Keterampilan Berbicara Siswa SD. Jurnal Ilmiah Sekolah Dasar, 4(1).

Priani, I. (2019). Priani, Irul. 2019. Pengaruh Model Problem Based Learning (PBL) Berbantuan Media Gambar Terhadap Hasil Belajar IPA Siswa Kelas V Gugus III Kuta Utara Tahun Pelajaran 2017/2018. MIMBAR PGSD, 7(1).

Putri, N. M. canessia. (2019). Pengaruh Model Discovery Learning Berbantuan Lingkungan Terhadap Kompetensi PengetahuanIPA Siswa Kelas V. MIMBAR $P G S D, 7(2)$

Rani, N. M. A. M. (2019). Pengaruh Model Pembelajaran Talking Stick Berbantuan Lagu Tradisional Terhadap Kompetensi Pengetahuan IPA. MIMBAR ILMU, 24(3)

Safitri, N. P. L. (2020). Pengaruh Model Pembelajaran Creative Problem Solving Berbantuan Eksperimen Terhadap Kompetensi Pengetahuan IPA Siswa Kelas V. MIMBAR ILMU, volume 25(1)

Setyosari, P. (2016). Metode Penelitian Pendidikan \& Pengembangan.

Shoimin, A. (2014). 68 Model Pembelajaran Inovatif dalam Kurikulum 2013.

Suandewi, N. putu. (2017). Pengaruh Model Pembelajaran Nos Untuk Meningkatkan Hasil Belajar Ipa Melalui Lesson Study Siswa Kelas V. MIMBAR PGSD, 5(3).

Suciutari, N. P. D. (2013). Model Pembelajaran Accelerated Learning Berfasilitas Multimedia Berpengaruh Terhadap Hasil Belajar Ipa Siswa Kelas V SD Gugus III Kecamatan Semarapura. MIMBAR PGSD, 1 (1)

Sugiyono. (2018). Metode Penelitian Kuantitatif Kualitatif dan R\&D.

Susanto, A. (2016). Teori Belajar dan Pembelajaran di Sekolah Dasar. 
Wahyuni, N. N. R. (2018). Pengaruh Model Pembelajaran Studen Team Achievementdivisions Berbantuan Media Questions Card Terhadap Hasil Belajar Matematika Siswa Kelas V SD Gugus IV Blahbatuh Tahun Ajaran 2017/2018. MIMBAR PGSD, 6(3)

Winata, P. K. A. (2017). Penerapan Pendekatan Saintifik Berbantuan Media Gambar Berseri Untuk Meningkatkan Kompetensi Ketrampilan Menulis Pada Bahasa Indonesia Siswa Kelas Vb SD N 9 Padangsambian Tahun Ajaran 2016/2017. MIMBAR PGSD, 5(3).

Yuniarti, D. (2019). Pengaruh Model Student Teams Achievement Divisions (STAD) Berbantuan Media Mind Mapping Terhadap Hasil Belajar IPS Siswa Kelas V SD Gugus III Kuta Utara Badung Tahun Ajaran 2017/2018. MIMBAR PGSD, 7(1). 